\title{
Karakteristik Kimia dan Fisik Bubur Instan Berbahan Dasar Tepung Jagung Pulut dan Tepung Kacang Merah
}

\author{
Chemical and Physical Characteristics of Instant Porridge Made from Waxy Corn and Red \\ Bean Flours
}

\section{Syane Palijama*, Rachel Breemer, Miranda Topurmera}

Jurusan Teknologi Hasil Pertanian, Fakultas Pertanian, Universitas Pattimura, Jl. Ir. M. Putuhena, Kampus Poka Ambon 97233

*Penulis korespondensi: Syane Palijama, e-mail: annie_jeane@yahoo.com

Tanggal submisi: 09 Maret 2020; Tanggal penerimaan: 22 April 2020

\begin{abstract}
People tend to choose their food practically and efficiently presented and made without reducing their nutritional content. The use of red bean flour is needed to replace protein sources while waxy rice flour contributes to carbohydrate replacement. The purpose of this study was to know and to determine the characteristics of instant porridge with the ratio of red bean flour and waxy corn flour. Results showed that the characteristics of instant porridge were influenced by the different ratios between red bean and waxy corn flour on instant porridge ash, protein, fat, fiber, carbohydrate contents as well as ask bulk density and rehydration powder. The ratio between corn and red bean flours of $80 \%$ and $20 \%$ resulted in instant porridge with moisture, protein, and carbohydrate of $3.44 \%, 10.8 \%$, and $80.53 \%$, respectively and met the quality standard set by SNI 01-7111.4-2005, an ash content of 1\%, a fat content of 0.76\% the fiber content of 3.79\%, bulk density of $1.03 \mathrm{~g} / \mathrm{mL}$, and rehydration power of $2.83 \mathrm{~mL} / \mathrm{g}$. . instant porridge, the ratio of red bean, and waxy flour.
\end{abstract}

Keywords: instant porridge, the ratio of red bean and waxy cornflour

\begin{abstract}
ABSTRAK
Masyarakat lebih memilih makanan yang dikonsumsi secara praktis dalam bentuk penyajian maupun dalam pembuatannya tanpa mengurangi pemenuhan kebutuhan gizi. Penggunaan tepung kacang merah diperlukan sebagai sumber protein dan penggunaan tepung jagung pulut sebagai pengganti karbohidrat. Tujuan dari penelitian adalah untuk mengetahui dan menentukan karakteristik bubur instan dengan rasio tepung kacang merah dan tepung jagung pulut. Hasil penelitian menunjukan bahwa karakteristik bubur instan dipengaruhi oleh rasio tepung kacang merah dan tepung jagung pulut yang berbeda terhadap kadar air, kadar abu, kadar protein, kadar lemak, kadar serat, kadar karbohidrat, densitas kamba dan daya rehidrasi. Hasil penelitian menunjukkan rasio tepung jagung pulut $80 \%$ dan tepung kacang merah $20 \%$ memiliki karakteristik kadar air (3,44\%), kadar protein $(10,8 \%)$ dan kadar karbohidrat $(80,53 \%)$ sesuai SNI 01-7111.4-2005, kadar abu $(1 \%)$, kadar lemak $(0,76 \%)$, kadar serat $(3,79 \%)$, densitas kamba $(1.03 \mathrm{~g} / \mathrm{mL})$ dan daya rehidrasi $(2.83$ $\mathrm{mL} / \mathrm{g})$.
\end{abstract}

Kata kunci: bubur instan, tepung jagung pulut dan tepung kacang merah 


\section{PENDAHULUAN}

Dewasa ini pola hidup masyarakat telah mengalami perubahan sehingga masyarakat lebih memilih mengkonsumsi makanan yang praktis dalam bentuk penyajian maupun pembuatannya tanpa mengurangi pemenuhan kebutuhan akan zat gizi yang diperlukan. Untuk mengatasi masalah tersebut diperlukan adanya diversifikasi untuk menciptakan produk yang mampu menjawab masalah tersebut. Menurut Almister (2010), diversifikasi pangan merupakan upaya untuk menganekaragamkan konsumsi pangan masyarakat dalam meningkatkan mutu gizi dan menghindari ketergantungan pada satu jenis makanan tertentu. Salah satu produk olahan pangan yang dapat dikembangkan adalah bubur instan karena memiliki tekstur yang lunak sehingga mudah dicerna. Bubur tidak hanya terbuat dari beras saja namun dapat pula dibuat dari beberapa bahan campuran seperti jagung dan kacang- kacangan.

Jagung pulut (Zea mays L.) merupakan salah satu komoditas yang potensial dan dapat dijadikan sebagai bahan dasar bubur instan selain beras. Jagung pulut merupakan salah satu komoditas pangan strategis dan bernilai ekonomi yang sangat tinggi serta mempunyai peluang untuk dikembangkan karena peranannya sebagai sumber utama karbohidrat yang memiliki komponen utama adalah pati $(72-73 \%)$, dengan perbandingan amilosa dan amilpektin 25\%-30\%:70-75\%, kandungan protein 7,1\% (Sugiyono et al., 2004). Jagung pulut juga mengandung zat gizi lain yaitu energi (150 kkal), protein $(1,6 \mathrm{~g})$, lemak $(0,60 \mathrm{~g})$, karbohidrat $(11,40$ g), kalsium (2 mg), fosfor (47 mg), serat $(0,40 \mathrm{mg})$, besi (0,30 mg), vitamin A (30 mg), vitamin B1 (0,07 $\mathrm{mg})$, vitamin B2 $(0,04 \mathrm{mg})$, vitamin C $(3,00 \mathrm{mg})$, niacin $(60 \mathrm{mg})$, dengan kandungan karbohidrat $74,26 \mathrm{~g}$ per $100 \mathrm{~g}$ bahan (Suarni et al., 2004). Sampai saat ini jagung pulut belum dapat diolah secara maksimal oleh masya-rakat sehingga belum dapat digunakan sebagai salah satu sumber pangan yang dapat mengatasi masalah pangan di Indonesia. Pada umumnya jagung pulut hanya diolah oleh masyarakat secara tradisional yaitu dengan cara dibakar, rebus, dan lain-lain serta dikeringkan untuk kebutuhan pakan ternak sehingga perlu pengolahannya dalam bentuk tepung. Jagung dalam bentuk tepung lebih fleksibel, tahan lama, praktis dapat diperkaya dengan zat gizi (fortifikasi), dan lebih cepat dimasak (Damardjati et al., 2000; Suarni dan Firmansyah, 2005). Penelitian tentang pemanfaatan jagung pulut sebagai pangan instan telah dilakukan dengan menggunakan metode pembekuan dan pengeringan terhadap karakteristik grits jagung instan (Husain et al., 2016). Diversifikasi dilakukan untuk memperkaya kebutuhan gizi suatu produk sehingga penambahan kacang merah diperlukan untuk memenuhi kebutuhan protein bahan yang ditambahkan.

Kacang merah (Phaseolus vulgaris L.) merupakan komoditas kacang-kacangan dengan umur simpan relatif singkat sehingga perlu dilakukan penepungan untuk memudahkan aplikasinya sebagai tambahan pangan. Teknologi penepungan merupakan salah satu alternatif produk setengah jadi yang dianjurkan karena lebih tahan lama disimpan, mudah dicampur dengan tepung lainnya untuk memperkaya nilai gizi bahan pangan tersebut. Beberapa peneliti telah melakukan penelitian terhadap kacang merah antara lain Pramesta et al. (2012), mengkaji karakteristik sensori dan kimia bubur instan berbasis tepung kacang merah dan tepung milet putih. Selain itu, Yustiyani dan Setiawan (2013) mengkaji formulasi bubur instan menggunakan komposit tepung kacang merah dan pati ganyong. Untuk meningkatkan protein pada bubur instan maka diperlukan bahan pangan lain yaitu kacang merah karena kacang merah merupakan salah satu kacang yang potensial dan mudah didapat di Indonesia. Kacang merah memiliki lemak dan natrium yang sangat rendah, serta bebas kolesterol dan merupakan sumber serat yang baik. Kandungan gizi kacang merah dalam $100 \mathrm{~g}$ mengandung energi $336 \mathrm{kkal}$, protein $22,30 \mathrm{~g}$, lemak 1,5 g, karbohidrat $61,20 \mathrm{~g}$, kalsium 260,00 $\mathrm{mg}$, fosfor $410,00 \mathrm{mg}$, zat besi $80 \mathrm{mg}$, dan vitamin B 10,50 g (Astawan, 2009). Pembuatan bubur instan merupakan tahapan penting yang berfungsi untuk memperpanjang masa simpan dan memper-mudah pengemasan dan penyanjian. Produk akhir dari proses instanisasi bila ditempatkan dipermu-kaan air yang tidak dipanaskan maka bubuk akan tenggelam dan terdispersi tanpa pengadukan karena bubuk mempunyai kemampuan untuk menyerap air, tenggelam dan terdispersi (Hartomo dan Widiatmoko, 1993). Penggunaan pati pregelatinisasi dan tepung umbi-umbian telah dibuktikan dapat dibuat menjadi bubur instan sehingga dapat menghasilkan sifat produk yang baik dan mampu memberikan fungsi zat gizi yang tidak dimiliki oleh beras, seperti penggunaan pati garut dan tepung labu kuning yang memiliki kandungan betakaroten yang tinggi (Elvizahro, 2011).

Bubur instan yang merupakan sarapan berbasis serealia yang cukup baik dan dapat dikonsumsi baik dari usia balita maupun sampai usia lanjut (Srikaeo dan Sopade, 2010). Bubur 
instan merupakan bubur yang telah mengalami proses pengolahan lebih lanjut sehingga dalam penyajiannya tidak diperlukan proses pemasakan karena telah mengalami proses pemasakan sebelumnya. Penyajian bubur instan dapat dilakukan hanya dengan menambahkan air panas atau susu sesuai dengan selera. Menurut Hendy (2007), istilah instanisasi mencakup berbagai perlakuan, baik fisik maupun kimia yang dapat memperbaiki karakteristik hidrasi dari suatu produk pangan dalam bentuk serbuk. Cara instanisasi secara fisik adalah dengan pragelatinisasi yaitu memasak pati di dalam air sehingga tergelatinisasi sempurna, kemudian mengeringkan pasta pati yang dihasilkan, dan pati yang sudah tergelatinisasi memiliki sifat instan.

Penelitian ini bertujuan untuk mengkarakteristik sifat kimia dan sifat fisik bubur instan campuran tepung jagung pulut dan tepung kacang merah

\section{METODE PENELITIAN}

\section{Bahan}

Bahan yang digunakan dalam penelitian ini adalah tepung kacang merah sebanyak $5 \mathrm{~kg}$ dan jagung pulut $5 \mathrm{~kg}$, masing-masing bahan ini diambil pada tempat yang sama yaitu dari Desa Klis Kecamatan Moa Kabupaten Maluku Barat Daya. Kacang merah dan jagung pulut yang sudah kering diambil dari petani. Bahan untuk analisis kimia adalah $\mathrm{K}_{2} \mathrm{SO}_{4}, \quad \mathrm{H}_{2} \mathrm{SO}_{4}, \quad \mathrm{Na}_{2} \mathrm{~S}_{2} \mathrm{O}_{3}, \mathrm{H}_{3} \mathrm{BO}_{3}, \mathrm{HCl}$ (Riedel-de Haën, Jerman).

Rancangan yang digunakan dalam penelitian ini adalah rancangan acak langkap satu faktor dengan empat taraf perlakuan dan tiga kali ulangan. Sebagai perlakuan adalah tepung jagung pulut dan tepung kacang merah $(\% \quad \mathrm{~b} / \mathrm{b})$ yang perbandingannya bervariasi yaitu 80:20, 60:40, 40:60 dan 20:80. Penelitian ini dilaksanakan di Laboratorium Teknologi Hasil Pertanian, Fakultas Pertanian, Universitas Pattimura.

\section{Pembuatan Bubur Instan}

Jagung pulut dan kacang merah dilakukan sortasi dan pencucian dilanjutkan dengan pengeringan dengan cara dijemur selama 2 hari. Tahap selanjutnya adalah pengecilan ukuran dan pengayakan dengan menggunakan ayakan 80 mesh. Pembuatan bubur instan dilakukan dengan mencampur semua bahan sedikit demi sedikit sesuai dengan formulasi. Campuran bahan ditambahkan air, lalu dimasak selama 10 menit dengan suhu $75^{\circ}$ $100^{\circ} \mathrm{C}$ hingga campuran bahan mengental. Bubur yang telah matang kemudian didinginkan dan dioleskan di atas loyang yang sudah dilapisi aluminuim foil, kemudian bubur dikeringkan di dalam oven listrik (Cosmos, Indonesia) selama 3 jam dengan suhu $125^{\circ} \mathrm{C}$. Setelah kering, bubur dihaluskan dengan blender (Cosmos, Indonesia), bubur yang sudah halus tersebut lalu dikeringkan lagi didalam oven listrik selama 15 menit dengan suhu $100^{\circ} \mathrm{C}$. Bubur yang sudah kering selanjutnya dihaluskan lagi dengan crusher dan diayak menggunakan ayakan 80 mesh (Tamrin dan Pujilestari, 2016). Formulasi bubur instan tepung jagung pulut dan tepung kacang merah dapat dilihat pada Tabel 1 .

Tabel 1. Formulasi bubur instan tepung jagung pulut dan tepung kacang merah yang telah dimodfikasi (Tamrin dan Pujilestari, 2016)

\begin{tabular}{lc}
\hline \multicolumn{1}{c}{ Jenis Bahan } & $\begin{array}{c}\text { Persentasi } \\
(\mathrm{w} / \mathrm{w})\end{array}$ \\
\hline Tepung jagung pulut dan tepung & $10,45 \%$ \\
kacang merah & \\
Susu bubuk skim & $8,62 \%$ \\
Gula halus & $0,86 \%$ \\
Minyak nabati & $1,72 \%$ \\
Air & $78,35 \%$ \\
\hline
\end{tabular}

Variabel yang diamati pada bubur instan ini meliputi karakteristik kimia yaitu kadar air, abu, protein, lemak, karbohidrat dan serat sedangkan karakteristik fisik yaitu densitas kamba dan daya rehidrasi.

\section{Kadar Air (AOAC, 1995)}

Cawan kosong dikeringkan dalam oven selama 15 menit, lalu didinginkan dalam desikator, dan ditimbang. Sebanyak $5 \mathrm{~g}$ sampel ditimbang dalam cawan yang telah diketahui bobot kosongnya, lalu dikeringkan dalam oven pengering (Memmert, Germany) pada suhu $105^{\circ} \mathrm{C}$ selama 6 jam. Cawan dengan isinya kemudian didinginkan dalam desikator, dan ditimbang. Pengeringan dilakukan kembali hingga diperoleh berat konstan. Kadar air dihitung berdasarkan kehilangan bobot yaitu selisih bobot awal sampel sebelum dikeringkan dengan bobot akhir setelah dikering-kan. 


\section{Kadar Abu (AOAC, 1995)}

Cawan porselen dipanaskan dalam oven (Memmert, Germany) selama 15 menit, lalu didinginkan dalam desikator dan ditimbang. Sebanyak $5 \mathrm{~g}$ sampel dimasukkan dalam cawan porselen dan ditimbang, lalu dibakar sampai tidak berasap lagi dan diabukan dalam tanur ((Vulcan A$550 \mathrm{Ney}, \mathrm{AS})$ bersuhu $550^{\circ} \mathrm{C}$ sampai berwarna putih (semua contoh menjadi abu). Setelah itu didinginkan dalam desikator dan ditimbang sampai mendapatkan bobot konstan.

\section{Kadar Protein, Metode Semi Mikro-Kjeldahl (AOAC, 1995)}

Sampel ditimbang 0,2 g dalam labu kjeldahl $30 \mathrm{~mL}$, ditambahkan $1,9+0,1 \mathrm{~g} \mathrm{~K}_{2} \mathrm{SO}_{4}$, dan 2,0 + $0,1 \mathrm{~mL} \mathrm{H}_{2} \mathrm{SO}_{4}$ pekat. Sampel didestruksi selama 11,5 jam sampai cairan menjadi jernih. Cairan didinginkan, ditambah 8-10 mL NaOH- $\mathrm{Na}_{2} \mathrm{~S}_{2} \mathrm{O}_{3}$ dan dimasukkan ke dalam alat destilasi. Di bawah kondensor alat destilasi diletakkan erlenmeyer berisi $5 \mathrm{~mL}$ larutan $\mathrm{H}_{3} \mathrm{BO}_{3}$ dan beberapa tetes indikator metil merah. Ujung selang kondensor harus terendam larutan untuk menampung hasil destilasi sekitar $15 \mathrm{~mL}$. Distilat dititrasi dengan $\mathrm{HCl}$ 0,02 N sampai terjadi warna abu-abu. Prosedur yang sama juga dilakukan terhadap blanko (tanpa sampel). Jumlah titrasi sampel (a) dan titrasi blanko (b) dinyatakan dalam $\mathrm{mL} \mathrm{HCl} \mathrm{0,02} \mathrm{N.} \mathrm{Kadar}$ Protein $(\%)=$ Kadar $\mathrm{N}(\%) \times 6,25$.

\section{Kadar Lemak Metode Soxhlet (AOAC, 1995)}

Metode yang digunakan dalam analisis lemak adalah metode ekstraksi Soxhlet. Labu lemak yang akan digunakan dikeringkan dalam oven, kemudian didinginkan dalam desikator lalu ditimbang. Sebanyak $5 \mathrm{~g}$ contoh dibungkus dengan kertas saring, kemudian kertas saring yang berisi contoh tersebut dimasukkan ke dalam alat ekstraksi Soxhlet. Alat kondensor diletakkan di atasnya dan labu lemak diletakkan di bawahnya. Pelarut hexana dimasukan ke dalam labu lemak secukupnya. Selanjutnya dilakukan refluks selama minimal 5 jam sampai pelarut yang turun kembali ke dalam labu lemak berwarna jernih. Pelarut yang ada dalam labu lemak didestilasi, dan pelarut ditampung kembali. Kemudian labu lemak yang berisi lemak hasil ekstraksi dipanaskan dalam oven (Memmert, Germany) pada suhu $105^{\circ} \mathrm{C}$ hingga mencapai berat tetap, kemudian didinginkan dalam desikator. Selanjutnya labu beserta lemak ditimbang.

\section{Kadar Serat Kasar (AOAC, 1995)}

Sampel sebanyak $1 \mathrm{~g}$ dimasukkan ke dalam labu erlenmeyer $300 \mathrm{~mL}$ kemudian ditambah dengan $\mathrm{H}_{2} \mathrm{SO}_{4} \quad 0,3 \mathrm{~N}$ di bawah pendingin balik kemudian dididihkan selama 30 menit dengan kadang-kadang digoyang-goyangkan. Suspensi disaring dengan kertas saring, dan residu yang didapat dicuci dengan air mendidih hingga tidak bersifat asam lagi (diuji dengan kertas lakmus). Residu dipindahkan ke dalam erlenmeyer, sedangkan yang tertinggal di kertas saring dicuci kembali dengan $200 \mathrm{~mL} \mathrm{NaOH}$ mendidih sampai semua residu masuk kedalam erlenmeyer. Sampel dididihkan kembali selama 30 menit dan disaring sambil dicuci dengan larutan $\mathrm{K}_{2} \mathrm{SO}_{4} 10 \%$. Residu dicuci dengan $15 \mathrm{~mL}$ alkohol 95\%, kemudian kertas saring dikeringkan pada $110{ }^{\circ} \mathrm{C}$ sampai berat konstan lalu ditimbang.

\section{Kadar Karbohidrat (by difference)}

Kadar karbohidrat di peroleh dari hasil pengurangan angka dengan presentasi komponen lain (air, abu, lemak, protein dan serat kasar). Bila hasil pengurangan ini di kurangi dengan presentasi serat, maka di peroleh karbohidrat yang di cerna.

\section{Densitas Kamba (Bulk) (Wiratkusumah et al., 1992)}

Densitas kamba adalah masa partikel yang menempati suatu unit volume tertentu. Densitas kamba ditentukan oleh berat wadah yang diketahui volumenya dan merupakan hasil pembagian bubuk dengan volume wadah. Sampel dimasukan kedalam piknometer $100 \mathrm{~mL}$. Isi hingga volumenya mencapai tepat $100 \mathrm{~mL}$ lalu ditimbang bobotnya. Densitas kamba dapat dihitung dengan rumus:

$$
\text { Densitas kamba }(\mathrm{g} / \mathrm{mL})=\frac{\text { berat sampel }(\mathrm{g})}{\text { volume }(\mathrm{mL})}
$$

\section{Daya Rehidrasi (Beuchat, 1997)}

Sampel sebanyak $1 \mathrm{~g}$ ditambahkan $10 \mathrm{~mL}$ air dan diaduk. Diamkan 30 menit pada suhu kamar. Selanjutnya campuran disentrifius dengan kecepatan $3500 \mathrm{rpm}$ selama 30 menit. Daya rehidrasi dihitung dengan rumus:

$$
\text { Daya rehidrasi }(\mathrm{mL} / \mathrm{g})=\frac{\mathrm{A}-\mathrm{B}}{\mathrm{C}}
$$


Keterangan: $\mathrm{A}=$ Volume air mula mula $(\mathrm{mL}) ; \mathrm{B}=$ Volume supernatan $(\mathrm{mL}) ; \mathrm{C}=$ Bobot sampel $(\mathrm{g})$

\section{HASIL DAN PEMBAHASAN}

Hasil penelitian terhadap karakteristik kimia dan fisik bubur instan menunjukkan bahwa kadar abu, protein, lemak, karbohidrat dan daya rehidrasi berpengaruh nyata sedangkan kadar air, serat dan densitas kamba tidak berpengaruh nyata (Tabel 2 dan Tabel 3).

\section{Kadar Air}

Hasil analisis ragam bubur instan terhadap semua perlakuan tidak berpengaruh nyata terhadap kadar air. Tabel 2 menunjukkan bahwa nilai rataan kadar air bubur instan tertinggi terdapat pada perlakuan rasio tepung jagung pulut $80 \%$ dan tepung kacang merah $20 \%$ yaitu sebesar $5,54 \%$ sedangkan nilai rataan kadar air bubur instan terendah terdapat pada perlakuan rasio tepung jagung pulut 20\% dan tepung kacang merah $80 \%$ yaitu sebesar $3,4 \%$. Hal ini sesuai dengan pendapat Chilmijati (1999), bahwa tepung yang memiliki kandungan protein yang lebih tinggi bersifat menyerap air lebih kuat dibandingkan tepung dengan kandungan protein yang rendah. Kadar protein bubur instan meningkat dengan bertambahnya konsentrasi tepung kacang merah yaitu berkisar antara 10,80-20,02\%. Semakin tinggi kadar protein bubur instan maka kadar air juga semakin meningkat. Pada penelitian yang dilakukan, kadar air bubur instan perlakuan rasio tepung kacang merah $20 \%$ dan tepung jagung pulut $80 \%$ sudah memenuhi persyaratan yang ditentukan oleh SNI, sedangkan pada perlakuan rasio tepung kacang merah dan tepung jagung (40:60), (60:40) dan (80:20) sudah melebihi standard yang ditetapkan SNI bubur instan maksimal $4 \mathrm{~g} / 100 \mathrm{~g}$ bahan.

\section{Kadar Abu}

Hasil analisis ragam bubur instan terhadap semua perlakuan berpengaruh nyata $(P<0,05)$ terhadap kadar abu. Tabel 2 menunjukkan bahwa nilai rataan kadar abu bubur instan tertinggi terdapat pada perlakuan rasio tepung jagung pulut $80 \%$ dan tepung kacang merah $20 \%$ yaitu sebesar 3,8\% sedangkan nilai rataan kadar abu bubur instan terendah terdapat pada perlakuan rasio tepung jagung pulut $20 \%$ dan tepung tepung kacang merah $80 \%$ yaitu sebesar $1,0 \%$.

Hal ini dikarenakan kadar abu memiliki hubungan erat dengan kandungan mineral suatu bahan, yaitu kacang merah memiliki kandungan mineral sebesar 3,7\% dalam $100 \mathrm{~g}$ bahan sedangkan jagung memiliki kandungan mineral yaitu zat besi $0,40 \mathrm{mg}$, magnesium $0,01 \mathrm{mg}$, dan potasium 0,60 mg (Suarni dan Firmansyah, 2005). Pada penelitian yang dilakukan, kadar abu bubur instan yang diperoleh sudah memenuhi persyaratan yang ditentukan oleh SNI yaitu maksimal 3,5 g/100 g bahan.

Tabel 2. Karakteristik kimia bubur instan dengan formulasi tepung jagung pulut dan tepung kacang merah

\begin{tabular}{lcccc}
\hline \multirow{2}{*}{ Variable } & \multicolumn{4}{c}{ Formulasi Tepung Jagung Pulut dan Tepung Kacang Merah } \\
\cline { 2 - 5 } & $80: 20$ & $60: 40$ & $40: 60$ & $20: 80$ \\
\hline Kadar air (\%) & $5,54 \mathrm{a}$ & $4,69 \mathrm{a}$ & $4,30 \mathrm{a}$ & $3,44 \mathrm{a}$ \\
Kadar abu (\%) & $3,8 \mathrm{a}$ & $2,6 \mathrm{ab}$ & $1,2 \mathrm{bc}$ & $1,0 \mathrm{c}$ \\
Protein (\%) & $20,02 \mathrm{a}$ & $17,04 \mathrm{~b}$ & $13,58 \mathrm{c}$ & $10,8 \mathrm{~d}$ \\
Lemak (\%) & $1,77 \mathrm{a}$ & $1,59 \mathrm{ab}$ & $1,14 \mathrm{bc}$ & $0,76 \mathrm{c}$ \\
Serat (\%) & $4,63 \mathrm{a}$ & $3,96 \mathrm{a}$ & $3,95 \mathrm{a}$ & $3,79 \mathrm{a}$ \\
Karbohidrat (\%) & $80,53 \mathrm{a}$ & $75,81 \mathrm{~b}$ & $70,1 \mathrm{c}$ & $64,29 \mathrm{~d}$ \\
\hline
\end{tabular}

Keterangan: Angka yang diikuti huruf yang sama pada baris yang sama tidak berbeda nyata berdasarkan uji BNJ ( $\alpha=$ $0,05)$.

Tabel 3. Karakteristik fisik bubur instan dengan formulasi tepung jagung pulut dan tepung kacang merah

\begin{tabular}{lcccc}
\hline \multirow{2}{*}{ Variable } & \multicolumn{4}{c}{ Formulasi Tepung Jagung Pulut dan Tepung Kacang Merah } \\
\cline { 2 - 5 } & $80: 20$ & $60: 40$ & $40: 60$ & $20: 80$ \\
\hline Densitas kamba $(\mathrm{g} / \mathrm{mL})$ & $1,03 \mathrm{a}$ & $1,03 \mathrm{a}$ & $1,02 \mathrm{a}$ & $1,01 \mathrm{a}$ \\
Daya rehidrasi $(\mathrm{mL} / \mathrm{g})$ & $2,83 \mathrm{~b}$ & $3,03 \mathrm{ab}$ & $3,16 \mathrm{ab}$ & $3,56 \mathrm{a}$ \\
\hline
\end{tabular}

Keterangan: Angka yang diikuti huruf yang sama pada baris yang sama tidak berbeda nyata berdasarkan uji BNJ ( $\alpha=$ $0,05)$. 


\section{Kadar Protein}

Hasil analisis ragam bubur instan terhadap semua perlakuan berpengaruh nyata $(P<0,05)$ terhadap kadar protein. Tabel 2 menunjukkan bahwa nilai rataan kadar protein bubur instan tertinggi terdapat pada perlakuan rasio tepung jagung pulut $80 \%$ dan tepung kacang merah $20 \%$ yaitu sebesar $20,02 \%$ sedangkan nilai rataan protein bubur instan terendah terdapat pada perlakuan rasio tepung jagung pulut $20 \%$ dan tepung kacang merah $80 \%$ yaitu sebesar $10,8 \%$. Kandungan protein kacang merah lebih tinggi 22,30 g/100 g bahan (Astawan, 2009), dibandingkan kandungan protein tepung jagung pulut 1,6 g/100 g bahan (Sugiyono et al., 2004).

Hasil penelitian menunjukkan bahwa total rataan protein bubur instan tepung jagung pulut dan tepung kacang merah semakin meningkat dengan adanya penambahan tepung kacang merah. Hal ini sesuai dengan pendapat Munte et al. (2019), yang menyatakan bahwa kandungan protein tepung kacang merah adalah tinggi (16,27\%). Pada penelitian yang dilakukan, bubur instan sudah memenuhi persya-ratan yang ditentukan oleh SNI yaitu minimal 8-22 g/100 g bahan.

\section{Kadar Lemak}

Hasil analisis ragam bubur instan terhadap semua perlakuan berpengaruh nyata $(P<0,05)$ terhadap kadar lemak. Tabel 2 menunjukkan bahwa nilai rataan kadar lemak bubur instan tertinggi terdapat pada perlakuan rasio tepung jagung pulut $80 \%$ dan tepung kacang merah $20 \%$ yaitu sebesar $1,77 \%$ sedangkan nilai rataan kadar lemak bubur instan terendah terdapat pada perlakuan rasio tepung jagung pulut $20 \%$ dan tepung kacang merah $80 \%$ yaitu sebesar $0,76 \%$.

Hal ini menunjukkan bahwa rasio tepung jagung pulut dan tepung kacang merah yang berbeda berpengaruh terhadap kadar lemak bubur instan yang dihasilkan, apabila semakin banyak penambahan tepung kacang merah dalam pembuatan bubur instan maka semakin tinggi pula kadar lemak yang dihasilkan.

Sesuai dengan pendapat Astawan (2009), mengatakan bahwa setiap $100 \mathrm{~g} /$ bahan kacang merah mengandung 1,5 g lemak sedangkan menurut Suarni et al. (2004), jagung pulut hanya memiliki lemak sebesar 0,60 g/100 g bahan. Pada penelitian yang dilakukan, kadar lemak bubur instan yang diperoleh masih sangat kecil dan belum memenuhi standar yang ditetapkan oleh SNI yaitu minimal 6$15 \mathrm{~g} / 100 \mathrm{~g}$ bahan.

\section{Kadar Serat}

Hasil analisis ragam bubur instan terhadap semua perlakuan tidak berpengaruh nyata terhadap kadar serat. Tabel 2 menunjukkan bahwa nilai rataan kadar serat bubur instan tertinggi terdapat pada perlakuan rasio tepung jagung pulut $80 \%$ dan tepung kacang merah $20 \%$ yaitu sebesar $4,63 \%$ sedangkan nilai rataan kadar lemak bubur instan terendah terdapat pada perlakuan rasio tepung jagung pulut 20\% dan tepung kacang merah $80 \%$ yaitu sebesar 3,79\%.

Semakin tinggi penambahan tepung kacang merah dalam pembuatan bubur instan maka semakin tinggi pula kadar serat yang diperoleh. Tepung kacang merah memiliki kandungan serat pangan sebesar 3,76 g/100 g bahan sedangkan jagung pulut memiliki kandungan serat pangan sebesar 1,62 g/100 g bahan (Suarni et al., 2005). Berdasarkan SNI 01-7111.4-2005, kadar serat pada bubur instan maksimal $3 \mathrm{~g} / 100 \mathrm{~g}$ bahan. Hasil penelitian terhadap bubur instan berbahan dasar tepung jagung pulut dan tepung kacang merah menunjukkan kisaran antara 3,79-4,63\% maka kadar serat kasar yang dihasilkan sudah melebihi anjuran yang ditentukan oleh SNI, namun hal ini tidak dapat mempengaruhi kandungan serat kasar yang diperoleh, karena menurut (Kusharto, 2006) untuk orang dewasa kandungan serat yang harus dikonsumsi tiap hari adalah sebesar 20-35 g atau 10$15 \mathrm{~g} / \mathrm{kkal}$.

\section{Kadar Karbohidrat}

Hasil analisis ragam bubur instan terhadap semua perlakuan berpengaruh nyata $(P<0,05)$ terhadap kadar karbohidrat. Tabel 2 menunjukkan bahwa nilai rataan kadar karbohidrat bubur instan tertinggi terdapat pada perlakuan rasio tepung jagung pulut $80 \%$ dan tepung kacang merah $20 \%$ yaitu sebesar $80,53 \%$ sedangkan nilai rataan kadar lemak bubur instan terendah terdapat pada perlakuan rasio tepung jagung pulut $20 \%$ dan tepung kacang merah $80 \%$ yaitu sebesar $64,29 \%$.

Dalam penelitian ini, kadar karbohidrat bubur instan ditentukan dengan metode by difference. Menurut Sugito dan Hayati (2006), kadar karbohidrat dipengaruhi oleh komponen nutrisi lain, semakin rendah komponen nutrisi lain maka kadar karbohidrat akan semakin tinggi. Komponen nutrisi yang mempengaruhi besarnya 
kadar karbohidrat diantaranya adalah kadar protein, lemak, air, abu, dan serat. Dalam penelitian ini hasil kadar karbohidrat bubur instan pada perlakuan rasio tepung jagung pulut $80 \%$ dan tepung kacang merah $20 \%$ belum memenuhi syarat yang ditetapkan oleh SNI bubur instan yaitu $77 \mathrm{~g} / 100 \mathrm{~g}$ bahan, namun pada perlakuan formulasi tepung jagung pulut $60 \%$ : tepung kacang merah $40 \%$, perlakuan rasio tepung jagung pulut $40 \%$ : tepung kacang merah $60 \%$ dan perlakuan rasio tepung jagung pulut $20 \%$ : tepung kacang merah $80 \%$ sudah memenuhi syarat yang ditentukan oleh SNI.

\section{Karakteristik Fisik Bubur Instan}

\section{Densitas Kamba}

Hasil analisis keragaman menunjukkan bahwa rasio tepung jagung pulut dan tepung kacang merah tidak berpengaruh nyata terhadap densitas kamba bubur instan. Tabel 3 menunjukkan bahwa nilai densitas semakin meningkat dengan bertambahnya konsentrasi tepung kacang merah, hal ini diduga karena kadar air kacang merah yang lebih tinggi dibandingkan dengan tepung jagung pulut. Menurut Wiratakusumah et al. (1992), parameter yang mempengaruhi densitas kamba salah satunya adalah kadar air. Kadar air bubur instan meningkat dengan bertambahnya konsentrasi tepung kacang merah yaitu berkisar antara 3,44-5,54\%.

Semakin tinggi kadar air, densitas kamba pun juga tinggi, sebab air dalam bahan dapat mengganggu dan menguraikan struktur protein sehingga butiran bahan menjadi porous (Wiratakusumah, 1992). Nilai densitas kamba bubur instan dengan perbandingan tepung kacang merah dan tepung jagung pulut berkisar antara 1,01$1,03 \mathrm{~g} / \mathrm{mL}$. Densitas kamba yang diperoleh dalam penelitian ini sudah melebihi standar yang ditetapkan. Dimana nilai densitas kamba untuk makanan berbentuk bubuk umumnya berkisar antara 0,3-0,8 g/mL (Tampubolon et al., 2014). Menurut Larasati et al. (2011), bahan pangan yang memiliki densitas kamba tinggi menunjukan kepadatan gizi yang tinggi. juga, selain itu densitas kamba tinggi juga menunjukkan bahwa produk tersebut lebih ringkas (non voluminous), artinya dalam volume tertentu yang sama, produk tersedia dalam berat yang lebih banyak. Semakin kecil densitas kamba maka produk tersebut makin porous sehingga dapat dikatakan bahwa densitas berbanding lurus dengan lama masak, dan berbanding terbalik dengan daya rehidrasi dan penyerapan air.

\section{Daya Rehidrasi}

Hasil analisis keragaman menunjukkan bahwa rasio tepung jagung pulut dan tepung kacang merah berpengaruh nyata $(P<0,05)$ terhadap daya rehidrasi bubur instan. Tabel 3 menunjukkan bahwa nilai rataan daya rehidrasi bubur instan tertinggi terdapat pada perlakuan rasio tepung jagung pulut $80 \%$ dan tepung kacang merah $20 \%$ yaitu sebesar $3,56 \mathrm{~mL} / \mathrm{g}$ sedangkan nilai rataan daya rehidrasi bubur instan terendah terdapat pada rasio tepung jagung pulut $20 \%$ dan tepung kacang merah $80 \%$ yaitu sebesar $2,83 \mathrm{~mL} / \mathrm{g}$.

Dalam penelitian ini daya rehidrasi bubur instan yang terbaik ada pada rasio tepung kacang merah $20 \%$ dan tepung jagung pulut $80 \%$, dimana kadar air bubur instan semakin meningkat maka semakin rendah juga daya rehidrasi yang diperoleh tetapi apabila kadar air bubur instan yang menurun akan menghasilkan daya rehidrasi yang baik. Hal ini sesuai dengan pendapat Widowati (2010), mengatakan bahwa semakin cepat produk dikeringkan maka semakin bagus pula kualitas proses rehidrasi karena pengeringan akan menghasilkan struktur porous yang akan memudahkan air untuk meresap ke dalam bubur instan pada saat proses penyeduhan dilakukan.

\section{KESIMPULAN}

Berdasarkan hasil penelitian yang telah diperoleh maka disimpulkan bahwa perlakuan rasio tepung jagung pulut $80 \%$ dan tepung kacang merah $20 \%$ menghasilkan bubur instan dengan karakteristik kimia meliputi kadar air $(3,44 \%)$, kadar abu (1\%), kadar protein (10,8\%), kadar lemak $(0,77 \%)$, kadar serat $(3,79 \%)$, kabohidrat $(80,19 \%)$ dan karakteristik fisik meliputi densitas kamba $(1,01 \%)$, daya rehidrasi $(3,56 \%)$,

\section{DAFTAR PUSTAKA}

Almister, S. 2010. Prinsip Dasar Ilmu Gizi. Jakarta: Gramedia Pustaka.

AOAC. 1995. Official Method of Analysis of The Association of Official Analytical Chemists. AOAC Inc., Arlington.

Astawan, M. 2009. Sehat dengan Kacang dan BijiBijian. Jakarta: Penebar Swadaya.

Beuchat, L.R. 1977. Functional and electrophoretic characteristics of succinyalated peanut flour protein. Journal of Agricultural and Food Chemistry 25: 258-261. DOI: 10.1021/jf60210a044 
Chilmijati, N. 1999. Karakteristik Pati Garut dan Pemanfaatannya sebagai Sumber Bahan Baku Glukosa Cair. Tesis. Progam Pasca Sarjana. Institut Pertanian Bogor. Bogor.

Damardjati, D.S., S. Widowati, J. Wargiono, dan S. Purba. 2000. Potensi dan Pendayagunaan Sumber Daya Bahan Pangan Lokal Serealia, Umbi-umbian, dan Kacang-kacangan untuk Penganekaragaman Pangan. Makalah pada Lokakarya Pengembangan Pangan Alternatif. Jakarta, 24 Oktober 2002.

Elvizahro, L. 2011. Kontribusi MP-ASI Bubur Bayi Instan dengan Substitusi Tepung Ikan Patin dan Tepung Labu Kuning terhadap Kecukupan Protein dan Vitamin A pada Bayi. Tesis. Program Studi Ilmu Gizi. Fakultas Kedokteran. Universitas Diponegoro, Semarang.

Hartomo, A.J. dan M.C. Widiatmoko. 1992. Emulsi dan Pangan Instan Berlesitin. Yogyakarta: Andi Offset.

Husain, H., T.R. Muchtadi, Sugijono, dan B. Haryanto. 2006. Pengaruh metode pembekuan da pengeringan terhadap karakteristik grits jagung instan. Jurnal Teknologi dan Industri Pangan 17: 189-196.

Hendy. 2007. Formulasi Bubur Instan Berbasis Singkong Sebagai Pangan Alternatif. Skripsi. Fakultas Teknologi Pertanian. Institut Pertanian Bogor.

Kusharto, C.M. 2006. Serat makanan dan perannya bagi kesehatan. Jurnal Gizi dan Pangan 1: 45-54.

Larasati. 2011. Kajian formulasi bubur bayi instan berbahan dasar pati garut (Maranta arundinaceae L.) sebagai makanan pendamping ASI (MP-ASI) terhadap sifat fisik dan organoleptik. Jurnal Teknologi Pangan dan Hasil Pertanian 5: 112-118.

Munte, E.T., L.M. Lubis, dan H. Sinaga. 2019. Pengaruh perbandingan tepung kacang merah (Phaseoulus vulgaris L.) dengan tepung labu kuning (Cucurbita moschata) dan suhu pengeringan terhadap sifat kimia dan sensori bubur instan. Jurnal Rekayasa Pangan dan Pertanian 7: 28-38.

Pramesta, L.D., D. Rachmawati, Kawiji, dan R.B.K. Anandito. 2012. Karakterisasi bubur bayi instan berbahan dasar tepung milet (Panicum sp.) dan tepung kacang merah (Phaseolus vulgaris L.) dengan flavor alami pisang ambon (Musa paradisiacal var. Sapientum L). Jurnal Teknosains Pangan 1: 32-40.
See, E.F., N.W.A. Wan, and A.A.A. Noor. 2007. Physico-chemical and sensory evaluation of breads supplemented with pumpkin flour. ASEAN Food Journal 14: 123-130.

Sinaga. 2002. Teknologi Hasil Hortikultura. Balitsa. Lembang. Bandung.

Suarni, A. Upe, dan Tj. Harlim. 2005. Karakteristik Sifat Fisik Dan Kandungan Nutrisi Bahan Setengah Jadi dari Jagung. Prosiding Seminar Nasional Kimia Teknologi Inovatif Pascapanen untuk Pengembangan Industri Berbasis Pertanian. Forum Kerja Kimia Kawasan Timur Indonesia. Palu. Hal. 87-92.

Suarni, dan I.U. Firmansyah. 2005. Beras Jagung: Prosesing dan Kandungan Nutrisi Sebagai Bahan Pangan Pokok. Prosiding Seminar dan Lokakarya Nasional Jagung. Makassar. Hal. 393-398.

Sugiyono, S.T. Soekarto, P. Hariyadi, dan A. Supriadi. 2004. Kajian optimasi teknologi pengolahan beras jagung instan. Jurnal Teknologi dan Industri Pangan 15: 119-128.

Sugito, dan A. Hayati. 2006. Penambahan daging ikan gabus dan aplikasi pembekuan pada pembuatan gluten. Jurnal Ilmu-Ilmu Pertanian Indonesia 8: 147-151.

Srikaeo, K. and P.A. Sopade. 2010. Functional properties and starch digestibility of instant jasmine rice porridges. Carbohydrate Polymers 82: 952-957. DOI: 10.1016/j.carbpol.2010.06.024

Tampubolon, N.L., T. Karo-Karo, dan Ridwansyah. 2014. Formulasi bubur bayi instan dengan substitusi tepung tempe dan tepung labu kuning sebagai alternatif makanan pendamping ASI. Jurnal Rekayasa Pangan dan Pertanian 2: 78-83.

Tamrin, R. dan S. Pujilestari. 2016. Karakteristik bubur bayi instan berbahan dasar tepung garut dan tepung kacang merah. Konversi 5 : 49-58.

Widowati, S., R. Nurjana, dan W. Amrinola. 2010. Proses pembuatan dan karakterisasi nasi sorgum instan. Prosiding Pekan Serealia Nasional. IPB. Bogor.

Wirakartakusumah, M.A., K. Abdullah dan A. M. Syarief. 1992. Sifat Fisik Pangan. PAU Pangan GIZI IPB, Bogor.

Yustiyani, dan B. Setiawan. 2013. Formulasi bubur instan menggunakan komposit tepung kacang merah dan pati ganyong sebagai makanan sapihan. Jurnal Gizi dan Pangan 8: 95-102. DOI: 10.25182/jgp.2013.8.2.95-102 